\title{
Piotr Koprowski
}

(Gdańsk)

\section{MALARSTWO IKONOWE TRADYCJI BIZANTYJSKIEJ}

\section{Abstract}

The article seeks to reflect upon the manner of perceiving reality (the so-called reversed perspective) associated with the Byzantine tradition of icon painting which was in evidence in the Ruthenian and Russian cultural circle from the $12^{\text {th }}$ to the first half of the $17^{\text {th }}$ century.

\section{Key words}

icon, icon painting, reversed perspective, the sacred, the profane, Byzantine tradition 
Wiele wskazuje na to, że historię sztuki można ujmować jako historię widzenia, jako następujące po sobie - w sensie chronologicznym - różnorakie sposoby postrzegania sfery sacrum i profanum ${ }^{1}$. Nie byłaby to jednak - dodajmy tytułem uzupełnienia - historia możliwości poznawczych ludzkiego oka, gdyż te od kilku tysięcy lat wydają się niezmienne. Chodziłoby natomiast o przemiany, uwarunkowania związane z kulturowym i religijno-etycznym odczytaniem dzieł sztuki, charakterystycznym dla danego okresu dziejowego. Nie oznacza to bynajmniej zakwestionowania swoistej hegemonii zmysłu wzroku. To oko odbiera bowiem „na pierwszy rzut” bodźce określonych jakości, a dopiero później ma miejsce całościowe odtworzenie widzianego. Dzieło sztuki jest więc efektem widzenia i wyrazem postrzegania przez artystę jakiejś cząstkowej rzeczywistości. Zostało ono również przeznaczone do oglądania, „oddane” odbiorcy. Postrzeganie tego ostatniego ma, podobnie jak w przypadku twórcy, charakter indywidualny. W związku z powyższym można skonstatować, że istnienie dzieła sztuki jest „rozpięte” między określonymi, jednostkowymi metodami widzenia. Chcąc poznać, zgłębić historię sztuki ujętą jako historię widzenia, należałoby zatem wyzyskać zarówno opisy doświadczeń twórców, jak i odbiorców. Nie można zapominać również o tym, że artyści są zawsze - w mniejszym lub większym stopniu - „dziećmi” swoich czasów, a więc i wyrazicielami dążeń odbiorców. Ta konstatacja natury ogólnej jest pomocna m.in. ze względów metodologicznych, kiedy „piszemy" historię sztuki rozumianą jako efekt percepcji.

Moim zamiarem jest dokonanie namysłu nad metodą odbioru rzeczywistości (tzw. odwróconą perspektywą) związaną z malarstwem ikonowym tradycji bizantyjskiej, obecną m.in. w ruskim i rosyjskim kręgu kulturowym w okresie od wieku XII do pierwszej połowy XVII². Żyli i tworzyli wówczas wybitni mistrzowie, „klasycy” sztuki ikonopisania, m.in. Alipij, Andriej Rublow, Teofan Grek, Dionizy, Prochorow Grodec, Prokofiej Szyryn, Istom i Nikifor Sawinowie ${ }^{3}$.

\footnotetext{
${ }^{1}$ Zob. m.in. J. Crary, Techniques of the Observer. On Vision and Modernity in the Nineteen Century, Cambridge 1992; J.S. Pasierb, Miasto na górze, Pelplin 2000; idem, Współczesna sztuka religijna i kościelna w Polsce, Rzym 1963.

${ }^{2}$ Malarstwo ikonowe stanowi integralną część dziedzictwa chrześcijańskiego. Jego korzenie można dostrzec zarówno na Wschodzie, jak i Zachodzie, jednak - ze względu na napięcia polityczne czasów karolińskich - nie zadomowiło się ono w obrębie cywilizacji łacińskiej. Ikona nie należy - co prawda - jedynie do prawosławia, ale "to ono ją chroniło i przekazało do naszych dni”. M. Quenot, Zmartwychwstanie i ikona, Białystok 2001, s. 70. Zob. także T.D. Łukaszuk, Obraz święty - ikona w życiu, w wierze i w teologii Kościoła, Częstochowa 1993, s. 88-99; O.Ju. Tarasow, Ikona i błagoczestije. Oczerki ikonnogo dieła w imperatorskoj Rosii, Moskwa 1995; T. Špidlik, I. Gargano, Duchowość Ojców greckich i wschodnich, Kraków 1997.

${ }^{3}$ Od drugiej połowy XVII w. pojawiają się na gruncie rosyjskiej sztuki ikonopisania wpływy zachodnie, co zdaniem niektórych badaczy skutkuje zatraceniem się rozumienia istoty ikon. Moż-
} 


\section{PERSPEKTYWA ODWRÓCONA I MALARSTWO IKONOWE}

Mówiąc o malarstwie - nie tylko ikonowym - trzeba pamiętać o tym, że niezwykle istotną dlań kwestią jest zarówno twórcza ekspresja postrzeganego otoczenia, jak i próba przeniesienia jej na płaską powierzchnię. Nie mamy tu do czynienia $\mathrm{z}$ „wpisaniem” przestrzennych wizji w ich trójwymiarową reprezentację. Nie jest to translacja wartości widzianych na jakości tworzone, lecz ich deformacja. W obrębie malarstwa przestrzeń zostaje pozbawiona głębi, w związku z czym nieodzowne jest ukazanie określonych planów za pomocą różnorakich technik o charakterze iluzyjnym. Na płaskiej przestrzeni obrazu trzeci wymiar rzeczywistości zastąpiono złudą, opartą na wyzyskaniu specyfiki ludzkiego oka w ogólności i jego niedoskonałości w szczególności. W tym kontekście pojawiła się perspektywa.

Posługując się terminem „perspektywa”" $\mathrm{w}$ odniesieniu do dzieł malarstwa, pragnę „oddać” widzenie wszystkiego: nie tylko płaskiej powierzchni obrazu, lecz również tego, co zostało - za sprawą umiejętnego wyzyskania iluzji - na nim ukryte. Chodzi - innymi słowy - o to, by widzieć to, co jest i to, czego, zdawałoby się, nie ma. W związku z powyższym trzeba m.in. poznać i zrozumieć techniki malarskie oddające iluzję oddalającego się tła uciekające linie, gradację jasności, stopniowanie barw, tonów. Mamy wówczas do czynienia z dosyć szerokim rozumieniem terminu "perspektywa"

$\mathrm{Na}$ perspektywę można spojrzeć również pod kątem wiążącego się z nią ładunku umowności. „Umowność perspektywy możemy porównać z umownością każdego języka, jakim się posługujemy”6 . Jest to język epoki historycznej, w jakiej żyjemy, język kultury, z którą jesteśmy związani, język naszego spojrzenia na człowieka i świat. Działania twórcy jawią się więc m.in. jako wyraz następstwa translacji języka otaczającej go rzeczywistości na język płaskiej przestrzeni reprezentacji. Są w związku z tym aktem świadomym - artysta dokonuje wyboru metody odczytania i zrozumienia określonego języka kultury, języka - dodajmy - widzianego wedle jakiegoś kodu.

W takiej sytuacji nieunikniony stał się konflikt między pragnieniem przedstawienia rzeczywistości w sposób jak najbardziej zgodny z naturą (z możliwościami ludzkiego oka) a jej wizją kulturowo-artystyczną. Wykry-

na jednak mówić o działalności w okresie po 1650 r. wielu spadkobierców tradycji „klasyków”ikonopisów. W XX w. do grona tych ostatnich należał m.in. pustelnik, ojciec Grigorij Krug.

${ }^{4}$ Słowo to pochodzi od łacińskiego perspecto, „oglądać do końca”.

${ }^{5}$ The Dictionary of Art, red. J. Turner, 24, London-New York 1996, s. 485.

${ }^{6} \mathrm{~B}$. Uspienski, O systemie przekazu obrazu w rosyjskim malarstwie ikon, [w:] E. Janus, M.R. Mayenowa (red.), Semiotyka kultury, Warszawa 1997, s. 331. 
stalizowały się więc dwa typy perspektyw: perspectiva naturalis i artificalis. Pierwsza $\mathrm{z}$ nich, początkowo w formie „nauki” przyrodniczo-matematycznej, umożliwiającej zgłębienie wiedzy o specyfice widzenia przedmiotów w naturze, ostatecznie przyjmuje postać koncepcji, której celem jest wierne przedstawianie przestrzeni dzięki naśladowaniu możliwości widzenia ludzkiego oka (do tej grupy należy m.in. perspektywa krzywoliniowa) ${ }^{7}$. Z kolei perspectiva artificalis, zwana też perspectiva pignendi albo practica, stawia sobie za cel:

racjonalne ujęcie przestrzeni obrazowej i wmieszanie w nią przedmiotów w odpowiednim "proporcjonalnym” pomniejszeniu. Dzisiaj nazywamy to perspektywą stosowaną, częścią geometrii wykreślnej ${ }^{8}$.

W dyskusji o perspektywie naturalnej i stosowanej nie mógł nie pojawić się aspekt semantyczny, ściśle wiążący się z artystycznym wyborem preferowanego typu sztuki: sztuki mimetycznej bądź będącej matematyczną kreacją rzeczywistości. Trzeba jednak w tym miejscu podkreślić, że nie jest to jednak „czysty” wybór typu: „albo - albo”. Nie można bowiem, będąc malarzem, zupełnie abstrahować od naukowego podejścia do widzenia. Dzieło malarskie $\mathrm{w}$ istocie posiada zawsze dwa plany perspektywiczne, dwa systemy przekazu: geometryczny i semantyczny. Geometryczny język perspektywy odpowiada za matematyczno-optyczne prawidłowości odchyleń perspektywy, za „stworzenie" zasady, wedle której konstytuowana jest przestrzeń malarska. Z kolei język semantyczny perspektywy oddaje znaczenia, sensy określonych elementów ikonicznych. Umożliwia ukazanie w dziele malarskim treści z zakresu sacrum. W semantycznym, odwróconym systemie perspektywy nie jest istotna matematyczna czy też optyczna prawidłowość, lecz umiejętnie zobrazowane doznanie transcendencji. $W$ tym przypadku decydujące znaczenie ma sfera znaczeniowa i wartościująca.

Perspektywa jest zatem formą symboliczną, operującą formalnym kształtem językowym i zarazem funkcjonującą jako określony sens lub zestaw sensów. Plan geometryczny konstytuuje jej sens linearny (bezpośredni przekaz językowy), zaś semantyczny - jest odpowiedzialny za prezentację wymowy, znaczenia dzieła. „Pełne”, całościowe oddziaływanie obrazowania perspektywicznego jest wynikiem wzajemnego wpływu tych przeciwstawnych, ale komplementarnych jakości. W dziełach malarskich relacje między tymi

\footnotetext{
${ }^{7}$ M. Rzepińska, Spór o perspektywę renesansową, [w:] Z. Liss et al. (red.), Studia Estetyczne, 1, Warszawa 1964, s. 217; R. Arnheim, Sztuka i percepcja wzrokowa, Warszawa 1978, s. 265.

${ }^{8}$ M. Rzepińska, Spór, s. 217.
} 
ostatnimi kształtowały się różnie. Wzajemny stosunek między tym, co widzialne, i tym, co jest poza zasięgiem ludzkiego oka, uzależniony był od celu przekazu. Perspektywa pełni również funkcję ikoniczną. Warto zatem przyjrzeć się dawnemu malarstwu ikonowemu i zobaczyć, w jaki sposób korzystało ono z planów perspektywicznych (geometrycznego i semantycznego).

\section{SYMBOLIKA IKONY JAKO WIZUALIZACJI WIARY}

Ikona jest widzialnym obrazem rzeczywistości nadprzyrodzonej, znakiem, który ma odpowiednio powiązać naznaczoną subiektywizmem percepcję z praobrazem (Bogiem), wprowadzić ludzką świadomość w obręb bezgrzesznego świata duchowego. Janusz Pasierb ujął istotę problematyki związanej z ikoną następująco:

Ikona jest bardzo szczególnym wizerunkiem sakralnym. Nie jest ona ilustracją, lecz (...) iluminacją. Tworzenie ikony (...) jest powtórzeniem aktu stworzenia świata. Ikona jest modelem pierwotnej, rajskiej, utraconej przez grzech i odzyskiwanej ostatecznej jedności: pragnie ona wziąć w nawias grzech pierworodny i usunąć wprowadzone przezeń w świat człowieka rozdarcie. Ikona jest ze świata i sponad świata. Sponad świata jest to, co sobór nicejski II w 787 roku nazwał prototypem. Kult ikony odnosi się do prototypu, Matki Bożej, jakiegoś świętego czy anioła, ale w ostatecznym sensie do Boga samego, jako źródła wszelkiej świętości i mocy. Ikona nie informuje o prototypie, ale go przypomina (jest anamnezą) i fascynuje nim. Obowiązuje wierność prototypowi, skodyfikowana w podręcznikach, zwanych hermenejami czy podlinnikami. Ikona (...) pobudza świadomość do duchowego oglądania pierwowzoru, który jest sponad świata. Dlatego ikonę maluje się na złocie, symbolizującym czyste światło. Ze świata pochodzi podobrazie. Materię świata symbolizuje deska, kość czy metal, na którym się tworzy wizerunek ${ }^{9}$.

Ikona dotyka sfery profanum, częściowo z niej wyrasta, wykraczając jednakże poza jej granice i zmierzając ku Bogu, będącemu wartością absolutną. Ikona (w szczególności ikona Acheiropoietes ${ }^{10}$ ) jest miejscem spotkania

${ }^{9}$ J.S. Pasierb, Jasnogórska Hodigitria, [w:] E. Bogusz (red.), Ikona. Symbol i wyobrażenie, Warszawa 1984, s. 107.

${ }^{10}$ Ikona Acheiropoietes należy do kategorii obrazu, który nie został „uczyniony ludzką ręką”. Pierwowzór tej ikony stanowi legendarny mandylion edesski. Legenda mówi, że trędowaty król Abgar, chcąc ujrzeć Chrystusa, posłał do niego swych dworzan. Jezus nie mógł spełnić życzenia króla i doń przybyć. Odbił więc cudownie swoją twarz na płótnie przeznaczonym dla owego władcy, tworząc $w$ ten sposób pierwszą ikonę stanowiącą fundament innych ikon. Paralelnym opowiadaniem dla tej legendy jest to o chuście św. Weroniki, na której Jezus Chrystus odbił własne oblicze. 
Stwórcy ze stworzeniem. Spotkanie to jest tym owocniejsze, im szybciej człowiek-odbiorca potrafi przejść ze stanu kontemplacji stricte estetycznej do stanu duchowej kontemplacji ikony. Nie chodzi tu bowiem w głównej mierze

o piękno estetyczne ikony, gdyż piękno ikony jest wewnętrzne i ma swoje źródło w Archetypie (Modelu). Jest oczywistym, że piękno nie odnosi się także do estetyki, gdyż odkrycie istoty ikony rozlewa światło wewnętrzne w tym, kto kontempluje ikonę ${ }^{11}$.

Piękno jest przedmiotem estetyki. Zdaniem teologów Bóg jest nie tylko pięknem, ale także - jak podkreśla Klemens z Aleksandrii - „przyczyną tego, co piękne”12. Ulryk ze Strasburga dodaje: „Bóg jest nie tylko doskonale piękny i jest najwyższym stopniem Piękna, ale jest też przyczyną sprawczą, wzorcową i celową wszelkiego stworzonego piękna"13. Piękno przejawia się również w wizerunku stworzonego na Boży obraz i podobieństwo człowieka. „Piękny ludzki kształt - twierdzi Michał Anioł Buonarotti - kocham dlatego, że jest Boga odbiciem" ${ }^{14}$. Nie można ponadto zapominać o tym, że piękno cechuje także twórczość jednostki ludzkiej. Odbiorca, delektując się obrazem, doświadcza więc czasami swoistego „wzlotu” duchowego. Jeśli percepcja ta dotyczy ikony, może wykrystalizować się stan prowadzący do metanoi, do oczyszczenia, nawrócenia, do wejścia w obręb rzeczywistości nadprzyrodzonej. Przekraczając granice percepcji estetycznej, zaczynamy sytuować się $\mathrm{w}$ sferze sacrum. Piękno - jak zauważa Pasierb - „staje się pośrednikiem wieczności”15. Poprzez immanentność wizerunku możliwe okazuje się uczestnictwo w życiu trójjedynego Boga. Człowiek-odbiorca staje się partnerem tego ostatniego, w swoisty sposób włączonym w sferę oddziaływania samej Trójcy Świętej. Plastycznie oddaje to m.in. ikoniczne wyobrażenie Trójcy Świętej Rublowa ${ }^{16}$.

Ze względu na fakt, że tematem ikon jest - generalnie rzecz ujmując - rzeczywistość transcendentalna, specyficzne staje się również „ukierunkowanie” perspektywy malarskiej. Celem ikonopisa jest przeniesienie na płaską powierzchnię materialną sfery świętej. W związku z tym bezpodstawna okazuje

Wskazuje się też na podobieństwo twarzy z Acheiropoietes do oblicza z Całunu Turyńskiego. Zob. G. Krug, Myśli o ikonie, Białystok 1991, s. 11-13; I. Jazykowa, Świat ikony, Warszawa 1998, s. 12.

${ }^{11}$ M. Quenot, Ikona. Okno ku wieczności, Białystok 1997, s. 8.

${ }^{12}$ Cyt. za: W. Tatarkiewicz, O filozofii i sztuce, Warszawa 1986, s. 185.

${ }^{13}$ Cyt. za: ibidem, s. 185.

${ }^{14}$ Cyt. za: ibidem, s. 186.

${ }^{15}$ J.S. Pasierb, Światło i sól, Paris 1983, s. 23.

${ }^{16}$ W. Cichosz, E. Pankowska-Siedlik, Teologiczna pedagogia ikony na przykładzie „Trójcy Świętej” Andrieja Rublowa, Studia Gdańskie 24, 2009, s. 119-138; T. Jank, Krótka historia niejednej ikony. Zarys historii, teologii i estetyki „malarstwa zbawiającego”, Gdańsk 1998. 
się iluzja głębi czy też zachowanie prawidłowych proporcji między poszczególnymi detalami. System perspektywy geometrycznej został zatem w ikonach zepchnięty na dalszy plan twórczych poszukiwań. Najważniejszy stał się system semantyczny, umożliwiający zachowanie relacji sensów i dokonywanie wartościowania poszczególnych elementów świata przedstawionego (elementów sfery sacrum). Twórcza ekspresja skupia się przede wszystkim na ukazaniu postaci - to one są pierwszorzędnymi elementami ikony. W związku z tym ulegają najmniejszej deformacji pod względem weryzmu przedstawienia $^{17}$.

W ikonach przedstawiających Jezusa Chrystusa w otoczeniu innych postaci on sam jest ukazany centralnie, jako symbol obecności w ludzkim losie, a więc zgodnie $z$ klasycznym schematem ikonograficznym. Inne postaci przedstawione są jako mniejsze lub na przykład „zasłonięte” postacią ważniejszą z punktu widzenia semantycznego. Ich twarze zawsze są zwrócone frontalnie do patrzącego odbiorcy dzieła ${ }^{18}$. Charakterystyczna w tym kontekście jest m.in. ikona „Anastasis” (Zstąpienie do piekieł - Zmartwychwstanie). Anastasis - Zmartwychwstanie jest rzeczywistością Chrystusa i człowieka ${ }^{19}$. Od VIII w. w tradycji prawosławnej zmartwychwstanie jest przedstawiane jako „zstąpienie do piekieł”, jako zejście Syna Bożego w ciemność ludzkiego upadku i śmierci. Chrystus jest Panem życia, światłością „wyrywającą” człowieka $\mathrm{z}$ otchłani. Na ikonie „Anastasis” Jezus chwyta w związku z tym za rękę Adama. Widoczny jest związek $\mathrm{z}$ bizantyjską liturgią: zmartwychwstanie Chrystusa jest zapowiedzią wskrzeszenia wszystkich zmarłych ${ }^{20}$. Zmartwychwstanie Jezusa to nie tylko zwycięstwo nad śmiercią fizyczną, ale również nad trapiącymi człowieka stanami trwogi, rozpaczy, rozdarcia, sprzeczności²1.

W ikonie ukazującej Maryję jako Hodegetrię ${ }^{22}$ wskazuje ona na Syna jako na jedynego pośrednika między Bogiem i człowiekiem, jako na „drogę” ku

\footnotetext{
${ }^{17}$ B. Uspienski, O systemie przekazu, s. 332.

${ }^{18}$ Ibidem, s. 322.

${ }^{19}$ Znamienny jest fragment Ewangelii wg św. Jana: „Ja jestem Zmartwychwstanie i Życie. Kto we mnie wierzy, choćby i umarł, żyć będzie” (J 11, 25).

${ }^{20}$ M. Quenot, Ikona, s. 120.

${ }^{21} \mathrm{~W}$. Hryniewicz, Misterium paschalne w życiu i myśli chrześcijańskiego Wschodu, W drodze 4, 1976, s. 22; idem, Tajemnica milczenia Boga. Medytacja teologiczna, Znak 2, 1995, s. 17. Sergiusz Bułgakow doda, że „Jestestwo ludzkie odsłania się jako ikona Boga od momentu, gdy objawiło się w Chrystusie. Ikona Chrystusa odtwarza Jego ludzki obraz, w którym wyobrażona jest i Jego Boskość". Idem, Myśli o ikonie, [w:] E. Bogusz (red.), Ikona, s. 6.

${ }^{22}$ Hodegetria - Wskazująca Drogę - jest ikoną maryjną. W ikonie tej postać Matki Bożej jest ukazana frontalnie. Na jednej ręce trzyma dzieciątko, wskazując na nie drugą ręką. Dzieciątko jedną ręką błogosławi swoją matkę, a w niej każdego człowieka, w drugiej zaś trzyma berło i jabłko lub zwój. I. Jazykowa, Podstawowe typy ikon Bogurodzicy w tradycji bizantyjsko-rosyjskiej oraz
} 
wieczności. Matka Boża potwierdza, że jednostka ludzka nie tylko może, ale wręcz powinna odnaleźć w sobie ikonę Boga, a w sposób szczególny - ikonę Chrystusa.

W celu zrozumienia ikony - podkreśla Sergiusz Bułgakow - należy wziąć za punkt wyjścia fakt wcielenia Słowa jako odsłaniający to, co dane już było przy stworzeniu człowieka. Człowiek jako taki, stworzony na obraz Boży, jest żywą ikoną Boga. Przestał nią być w następstwie grzechu pierworodnego, jednakże ta pierwotna ikoniczność przywrócona została mocą wcielenia. Jestestwo ludzkie odsłania się jako ikona Boga od momentu, gdy objawiło się w Chrystusie. Ikona Chrystusa odtwarza Jego ludzki obraz, w którym wyobrażona jest i Jego Boskość. Ikona Chrystusa pod pewnymi względami nie różni się wcale od ikony przedstawiającej człowieka. Podobnie jak i ta ostatnia, stanowi ona obraz człowieka, w którym wyjawia się zamieszkujący w nim duch $^{23}$.

Można więc - innymi słowy - skonstatować, że w perspektywie ikony jest usytuowana ludzkość, dopiero tutaj odnajdująca sens i pełnię swego istnienia. Owo dzieło malarskie jest sposobem wykraczania poza „skończoną”, horyzontalną rzeczywistość oraz wyrazem „zanurzania się” w blasku świata przemienionego, odkupionego. Ikona, niezależnie od tego, czy jest ikoną Acheiropoietes, Hodegetrii czy Trójcy Nowotestamentalnej ${ }^{24}$, jawi się również jako swoiste incarnatio Boga w ludzką kulturę oraz znikome, ale widoczne incarnatio ikonopisa. „Wcielanie się” piszącego ikonę nie oznacza pretendowania przezeń do zajęcia miejsca Boga w ikonie. Polega na pragnieniu delikatnego zarysowania własnej, twórczej indywidualności, wyrażającej się m.in. w przedstawieniu blasku światła czy też w natężeniu barwy. Pokazanie owej indywidualności nie oznaczało złamania zasad kanoniczności, zawartych w hermenei ${ }^{25}$. Kanoniczność zachowują klasyczne ikony m.in. takich twórców jak Teofan Grek, Dionizy, Rublow, mimo że są „naznaczone” pewną dozą subtelnego indywidualizmu.

ich interpretacja teologiczna, [w:] K. Pek (red.), Ikona liturgiczna, Warszawa 1999, s. 96; W. Kurpik, Częstochowska Hodegetria, Pelplin 2008.

${ }^{23}$ S. Bułgakow, Myśli o ikonie, s. 6.

${ }^{24}$ Ikona Trójcy Nowotestamentalnej ma świadczyć o Bożym Objawieniu. Występuje w niej postać starca, dojrzałego mężczyzny oraz gołębicy. Pod tymi postaciami ukazany jest Bóg Ojciec, Syn Boży i Duch Święty. W ruskiej ikonografii można wskazać na następujące warianty danego przedstawienia: Wspólny Tron, Ojcostwo, Przedwieczna Narada. I. Jazykowa, Świat ikony, s. 97.

${ }^{25}$ Hermeneja (inaczej podlinnik) jest zbiorem kanonicznych wzorców ikon. Jako obowiązującą ikonopisów wprowadził ją do użytku Sobór Stu Rozdziałów, obradujący w Moskwie w 1551 r. U podłoża tej decyzji leżała troska o kanoniczną czystość ikon. Warto dodać, że na soborze domagano się również właściwej postawy moralnej ze strony ikonopisów. Ibidem, s. 99, 154-155. 
Kanoniczność jest ściśle związana z tożsamością ikony. Ta ostatnia nie może utracić swojej wartości duchowej, prokontemplacyjnej na rzecz wartości estetycznej. Co więcej, ikona powinna rodzić w malarstwie pozasakralnym, nierzadko totalnie zeświecczonym, swoiste pragnienie sakralizacji, pragnienie przeobrażenia jego natury. „W takim przypadku ikona staje się - wedle Grzegorza Kruga - niebiańskim zaczynem zakwaszającym ciasto" ${ }^{26}$. Tego rodzaju dzieło jest również ze wszech miar potrzebne pragnącemu działać pozytywnie człowiekowi, przezwyciężyć chaos otaczającej go „ikonosfery”, a także światu ${ }^{27}$.

\section{IKONOPIS I JEGO FUNKCJA}

Paul Evdokimow wskazuje na to, że wschodnie pojmowanie obrazu-ikony różni się od zachodniego rozumienia obrazu religijnego. Na Zachodzie uwypukla się praktyczną funkcję obrazu religijnego (przypomnienie, rozumienie), twórca przekazuje treści o charakterze religijnym w sposób subiektywny, wypływający z jego indywidualnego natchnienia. Estetyczny immanentyzm obrazu religijnego zamyka się, zdaniem prawosławnego teologa, w relacji twórca - dzieło - odbiorca ${ }^{28}$. Zgoła odmiennie rzecz się przedstawia w odniesieniu do obrazu sakralnego, którym jest ikona. Ta ostatnia transponuje rzeczywistość przekraczającą wymiar wyłącznie ludzki. Przedstawiając w formie widzialnej, materialnej to, co niewidzialne i pozazmysłowe, jest w swojej strukturze wielowymiarowa i symboliczna. Sfera symboliczna jest zawarta $\mathrm{w}$ danym symbolu, ale pełnia symbolicznej wymowy pozostaje ostatecznie niewyrażalna, zastrzeżona dla oglądu wewnętrznego. Dzieło sztuki sakralnej prowadzi jednostkę ludzką do spotkania $\mathrm{z}$ transcendencją. W związku z tym wartości, jakimi operuje, muszą być obiektywne, uniwersalne, podporządkowane wynikającej z objawienia kosmologii i metafizyce. Zdaniem Evdokimowa tak postrzeganą ikonę należy umieścić w głębokich mrokach śmierci współczesnego świata, wśród zawiedzionych ludzkich nadziei. W ten sposób wypełniamy chrześcijańską misję:

Trzeba przejść przez chrzest, który jest śmiercią, by móc zmartwychwstać $\mathrm{w}$ świetle już nie ewangelicznym, ziemskim, kenotycznym, ale w rozbłysku

\footnotetext{
${ }^{26}$ G. Krug, Myśli o ikonie, s. 83.

${ }^{27}$ J. Nowosielski, Inność prawosławia, Białystok 1998, s. 159.

${ }^{28}$ P. Evdokimow, Poznanie Boga w tradycji wschodniej. Patrystyka, liturgia, ikonografia, Kraków 1996, s. 122; idem, Sztuka ikony. Teologia piękna, Warszawa 1999, s. 156-157.
} 
apokaliptycznego, ludzkiego oblicza Boga, już nie oblicza słodkiego Jezusa lecz strasznej i promiennej ludzkiej postaci trójjedynego Boga"29.

Chodzi o to, by kontemplacja ikony, albo raczej całego ikonostasu, zaowocowała odbudową wiary $\mathrm{w}$ możliwość przezwyciężenia rozdarcia człowieka i jego świata.

Paradoks czy niekonsekwencja? Ikona, jako całość ma charakter niesemiotyczny, nie jest znakiem i stanowi widzenie bezpośrednie, natomiast wewnątrz posługuje się znakami. Nie ma - podkreśla Władysław Panas - tu żadnej sprzeczności. Ikona przypomina i odsłania praobraz, utożsamia się z nim, ale przecież wychodzi z tego świata, z sytuacji po grzechu, z semiotyki upadku, z rozdwojenia; jest granicą i przestrzenią, w której dokonuje się ponownie koniunkcja. W ikonie dokonuje się połączenie $\mathrm{w}$ jednej przestrzeni tego, co dotychczas było rozbite na dwie przestrzenie. Znowu jakby jednym językiem przemawia Bóg i człowiek, znowu niewidzialne stało się widzialne, chociaż zachowało swą odrębnośćc ${ }^{30}$.

W tworzeniu ikony urzeczywistnia się powołanie artysty. W Kościele prawosławnym funkcja ikonopisa jest analogiczna do funkcji kapłana: obydwaj za pomocą właściwych środków (odpowiednio: słowa i barwy) pełnią posługę uobecniania Chrystusa. Piszący ikony, podejmując trud poszukiwania optymalnej formy do wyrażania wartości duchowych, świadomie rezygnował nie tylko z wszelkiego rodzaju dekoracyjności, z tego, co niekonieczne, zbędne, ale również z życia „światowego”. Jego egzystencja, podobnie jak twórczość, naznaczona była ascezą. Asceza (modlitwa, post, milczenie) była w tym przypadku przestrzenią obcowania z Bogiem. Wizja świata duchowego, oczyszczona przez wysiłek ascetyczny, jest „przeświadczeniem o rzeczach niewidzialnych"31. Artysta widzi głębię zjawisk przesyconą obecnością Ducha Świętego, jego dzieło to w związku z tym jednocześnie dzieło Boskiego Ikonografa. Doskonałość (lub niedoskonałość) materialnej formy nie może więc przesłonić ani zniekształcić prawd wiary. Prawdziwe piękno sacrum ma bowiem w owych prawdach swoje źródło. Ikona jest - w takiej optyce - owocem współpracy człowieka i Boga. Odzwierciedla jednak również - przynajmniej w pewnym stopniu - indywidualizm ikonopisa oraz stan duchowy epoki, w której została napisana. Przykładowo: jedną z cech charakterystycznych Teofana Greka jest intensywna kolorystyka i gra światła. Ikony Rublowa

\footnotetext{
${ }^{29}$ Idem, Prawosławie, Warszawa 1964, s. 298.

${ }^{30}$ W. Panas, Sztuka jako ikonostas, Znak 12, 1982, s. 1535; P. Florenski, Ikonostas i inne szkice, Białystok 1997.

${ }^{31}$ P. Evdokimow, Prawosławie, s. 278.
} 
tchną wyraźną równowagą i spokojem ducha ${ }^{32}$. Z kolei dzieła Dionizego emanują paschalną radością, zachwycają wirtuozerią linii i kolorów. Dla wszystkich tych oraz innych ikon autorstwa „klasyków” mniej istotna jest perspektywa geometryczna. Wskazuje na to przede wszystkim wykorzystywanie jej w dalszych planach oraz w mniej znaczących dla pojmowania sensu detalach. Twarze postaci, jako ważniejsze, ukazane są frontalnie, a ich ciała zgodnie z prawidłowymi, pod względem doświadczeń rzeczywistości materialnej, regułami układów ${ }^{33}$.

Właściwy ikonom „wewnętrzny” punkt widzenia nie ma nic wspólnego z postrzeganiem subiektywnym. Chodzi o to, by ich twórca, pozostając wiernym istniejącemu kanonowi ikonograficznemu, dał wyraz „religijnemu obiektywizmowi” oraz „ponadosobowej metafizyce" 34 . Malarstwo perspektywiczne ujmuje przedmioty w zgodzie $\mathrm{z}$ prawami optyki - w miarę jak oddalają się one w przestrzeni, stają się coraz mniejsze, w związku z czym coraz trudniej je rozpoznać. W malarstwie ikonowym obowiązuje zasada przeciwna: przedmioty znajdujące się $\mathrm{w}$ głębi ikony są nierzadko większe od tych, które są umieszczone na pierwszym planie. Mamy w tym przypadku do czynienia $\mathrm{z}$ zasadą odwróconej perspektywy, która nie polega jednak na zwykłym odwróceniu praw optyki, co jest charakterystyczne chociażby dla dzieł malarstwa kubistycznego, lecz na uwolnieniu się od optyki w ogóle $e^{35}$ - po to, by odsłonić rzeczywistość duchową, zakorzenioną w Bogu, a nie w ograniczonym spojrzeniu jednostki ludzkiej. Obrazy kubistów, mimo że zarzucają ujęcie perspektywiczne, stanowią zaprzeczenie sferze, jaką odsłania ikona. Nie odzwierciedlają ładu, lecz dysharmonię, chaos, nie „propagują” świętości

\footnotetext{
${ }^{32}$ Czytamy w wierszu współczesnego poety Franciszka Kameckiego „Ikony Rublowa”: „Któryś nijakość białych ścian

zaludnił niebiesko-żółtymi postaciami

o zamyślonych twarzach

$\mathrm{z}$ ciszą w dłoniach

wiedząc że ta cichość się sama obroni

i będzie wyjątkowa

pomiędzy wrzeszczącymi gębami

naszej epoki".

F. Kamecki, Epilogi Jakuba, Warszawa 1986, s. 66.

${ }^{33}$ M. Ałpatow, Rublow, Warszawa 1975; P.P. Gniedycz, Arcydzieła malarstwa rosyjskiego, Warszawa 2008; W. Mole, Ikona ruska. Pradzieje ikony ruskiej, Warszawa 1956; A. Siemaszko, K. Czerni, Andrej Rublow i ruskie ikony, Warszawa 2003.

${ }^{34}$ P. Florenski, Ikonostas, s. 219.

${ }^{35}$ B. Uspienski, Strukturalna wspólnota różnych rodzajów sztuki (na przykładzie malarstwa i literatury), [w:] E. Janus, M.R. Mayenowa (red.), Semiotyka kultury, Warszawa 1997, s. 181-212; Z. Podgórzec, Prolegomena do tematu „Semiotyka ikony”. Rozmowa z Borysem Uspienskim, Znak 270, 1976, s. 1611-1612.
} 
człowieka, ale jego destrukcję. Kubiści, pragnąc ukazać rzeczywistość z różnych punktów widzenia, deformują ją, rozczłonkowując przedmioty ${ }^{36}$.

Natomiast w malarstwie ikonowym:

semantycznie ważna część przedmiotu zwrócona jest ku widzowi (...), a semantycznie nieważna - podporządkowana jest perspektywicznym oddaleniom, ukazując rzeczywiste położenie przedmiotu w przestrzeni i stanowiąc tym samym klucz do prawidłowego rozmieszczenia przedmiotów w trzech wymiarach ${ }^{37}$.

W twórczości ikonopisów odrzucenie systemu geometrycznego ma miejsce zarówno w wyniku zaniechania korzystania z perspektywy linearnej, jak i w sytuacji, kiedy jakiś element kompozycji zostaje zarysowany w sposób nierealistyczny (przeczący widzeniu). Odpowiada to zaś w pełni prawidłom perspektywy semantycznej. Formy istotne ze względów semantycznych ukazane są przez twórców ikon w sposób nieodkształcony. Tylko elementy deformowane wskazują jednak na rzeczywisty układ przestrzenny w obrazie ${ }^{38}$. Ich zaburzenia w obrębie formy wynikają właśnie $\mathrm{z}$ tego, że są mniej istotne pod względem semantycznym.

\section{PODSUMOWANIE}

Relacje między odmiennymi planami perspektywicznymi w malarstwie ikonowym tradycji bizantyjskiej są w istocie dosyć skomplikowane. Jest tak ze względu na to, że plany te obecne są w dziele sztuki na zasadzie komplementarności. Kwestią istotną dla powstałego w tym kręgu kulturowym obrazu jest jednak semantyka przedstawienia, a geometryczny układ kompozycji stanowi tylko jej uzupełnienie. Wynika to w głównej mierze z funkcji, jaką ma pełnić ikona. Ta ostatnia ukazuje rzeczywistość sacrum, nie zatrzymuje wzroku odbiorcy na sobie samej, lecz kieruje wzrok ku Bogu, który sam jest pięknem. $\mathrm{W}$ związku z tym $\mathrm{w}$ przypadku przedstawień ikonicznych należy mówić o specyficznej, odwróconej perspektywie - perspektywie wartościującej (aksjologicznej), reprezentującej szerokie pole semantyki perspektywicznej. Semantyczność ikony pozwala na postrzeganie sfery sacrum poprzez brak podobieństwa do profanum.

\footnotetext{
${ }^{36}$ P. Szubert, Picasso i kubiści, [w:] Sztuka świata, 9, Warszawa 1996, s. 78-83.

${ }^{37}$ B. Uspienski, O systemie przekazu, s. 343.

${ }^{38}$ Ibidem, s. 340, 343.
} 


\section{Piotr Koprowski \\ BYZANTINE TRADITION IN ICON PAINTING}

\section{Summary}

Relations between various perspective-dependent planes in the Byzantine tradition of icon painting are in fact quite complex. This is due to the fact that the presence of those planes in a work of art is governed by the principle of complementarity. Nevertheless, an image created in that cultural circle the semantics of representation takes precedence, while the geometrical layout of the composition merely supplements the former. This largely results from the function that an icon is supposed to perform. An icon shows the reality of the sacred: instead of focusing and arresting the eye of the beholder on itself, it directs the gaze towards God, who is beauty incarnated. Hence iconic representations necessarily involve a singular, reversed perspective, a value-determining (axiological) perspective which represents a broad scope of perspectival semantics. The semanticity of and icon enables the sphere of the sacred to be perceived by virtue of lacking resemblance and similarity to the profane.

\section{Bibliografia}

Ałpatow M., Rublow, Warszawa 1975.

Arnheim R., Sztuka i percepcja wzrokowa, Warszawa 1978.

Cichosz W., Pankowska-Siedlik E., Teologiczna pedagogia ikony na przykładzie „Trójcy Świętej” Andrieja Rublowa, Studia Gdańskie 24, 2009.

Crary J., Techniques of the Observer. On Vision and Modernity in the Nineteen Century, Cambridge 1992.

Evdokimow P., Poznanie Boga w tradycji wschodniej. Patrystyka, liturgia, ikonografia, Kraków 1996.

Evdokimow P., Prawosławie, Warszawa 1964.

Evdokimow P., Sztuka ikony. Teologia piękna, Warszawa 1999.

Florenski P., Ikonostas i inne szkice, Bractwo Młodzieży Prawosławnej w Polsce, Białystok 1997.

Gniedycz P.P., Arcydzieła malarstwa rosyjskiego, Warszawa 2008.

Hryniewicz W., Misterium paschalne w życiu i myśli chrześcijańskiego Wschodu, W drodze 4, 1976, s. 15-28.

Hryniewicz W., Tajemnica milczenia Boga. Medytacja teologiczna, Znak 2, 1995, s. 12-26.

Ikona liturgiczna, red. K. Pek, Warszawa 1999.

Ikona. Symbol i wyobrażenie, red. E. Bogusz, Warszawa 1984.

Jank T., Krótka historia niejednej ikony. Zarys historii, teologii i estetyki „malarstwa zbawiającego", Gdańsk 1998.

Jazykowa I., Świat ikony, Warszawa 1998.

Kamecki F., Epilogi Jakuba, Warszawa 1986.

Krug G., Myśli o ikonie, Białystok 1991.

Kurpik W., Częstochowska Hodegetria, Pelplin 2008. 
Łukaszuk T.D., Obraz święty - ikona w życiu, w wierze i w teologii Kościoła, Częstochowa 1993.

Mole W., Ikona ruska. Pradzieje ikony ruskiej, Warszawa 1956.

Mrozek J., Trzeciak P., Włodarczyk P., Sztuka świata, 9, Warszawa 1996.

Nowosielski J., Inność prawosławia, Białystok 1998.

Panas W., Sztuka jako ikonostas, Znak 12, 1982, s. 1522-1542.

Pasierb J.S., Miasto na górze, Pelplin 2000.

Pasierb J.S., Światło i sól, Editions du dialogue, Paris 1983.

Pasierb J.S., Współczesna sztuka religijna i kościelna w Polsce, Rzym 1963.

Podgórzec Z., Prolegomena do tematu „Semiotyka ikony”. Rozmowa z Borysem Uspienskim, Znak 270, 1976.

Quenot M., Ikona. Okno ku Wieczności, Białystok 1997.

Quenot M., Zmartwychwstanie i ikona, Białystok 2001.

Semiotyka kultury, wyb. i oprac. E. Janus, M.R. Mayenowa, Warszawa 1997.

Siemaszko A., Czerni K., Andrej Rublow i ruskie ikony, Warszawa 2003.

Špidlik T., Gargano I., Duchowość Ojców greckich i wschodnich, Kraków 1997.

Studia Estetyczne, 1, red. Z. Lissa, Warszawa 1964.

Tarasow O.Ju., Ikona i błagoczestije. Oczerki ikonnogo dieła w imperatorskoj Rosii, Moskwa 1995.

Tatarkiewicz W., O filozofii i sztuce, Warszawa 1986.

The Dictionary of Art, 24, red. J. Turner, London-New York 1996. 